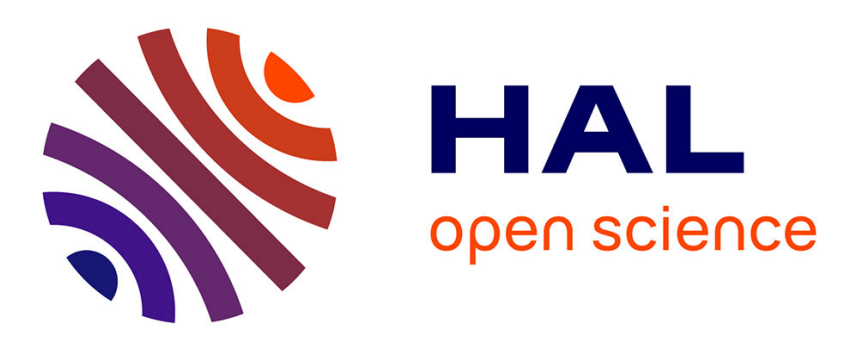

\title{
Observation of penetration with infrared thermography in laser welding
}

B. Grabas, J. Dard-Thuret, M. Laurent

\section{To cite this version:}

B. Grabas, J. Dard-Thuret, M. Laurent. Observation of penetration with infrared thermography in laser welding. Journal de Physique IV Proceedings, 1994, 04 (C4), pp.C4-139-C4-142. 10.1051/jp4:1994430 . jpa-00252693

\section{HAL Id: jpa-00252693 https://hal.science/jpa-00252693}

Submitted on 1 Jan 1994

HAL is a multi-disciplinary open access archive for the deposit and dissemination of scientific research documents, whether they are published or not. The documents may come from teaching and research institutions in France or abroad, or from public or private research centers.
L'archive ouverte pluridisciplinaire HAL, est destinée au dépôt et à la diffusion de documents scientifiques de niveau recherche, publiés ou non, émanant des établissements d'enseignement et de recherche français ou étrangers, des laboratoires publics ou privés. 


\title{
Observation of penetration with infrared thermography in laser welding
}

\author{
B. GRABAS, J. DARD-THURET and M. LAURENT
}

CETHIL, INSA de Lyon, URA D1372 du CNRS, Bât. 502, 69100 Villeurbanne, France

\begin{abstract}
The temperature field in every point of an homogeneous plate submitted to a moving heat source is obtained with a semi analytical method using Green's functions. This method is used to calculate the temperature field on and near the bead in laser welding and results are compared with the measurements obtained on one hand with an infrared thermography device and on the other hand with thermocouples located near the welding seam. The study was made with different plate thicknesses. The simulated and measured temperatures with infrared thermography on the welding bead concur at some distance behind the laser beam. The temperatures depend on the welding parameters and thus on the depth of the welded seam. It is therefore possible to control power and focus conditions in laser welding by infrared surface temperature measurement.
\end{abstract}

\section{Introduction}

In previous works temperature field in an homogeneous plate submitted to a moving heat source was determined with differents analytical models or different numerical modeling of the heat transfer. The analytical models related to moving heat source give a three dimensional temperature field for semi infinite materials or a two dimensional temperature field for thin plates. The temperature sources are either ponctual or specific energy distribution (for example gaussian sources) [1 à 10].

The semi analytical method used here gives a three dimensional field temperature [11]. The surface temperatures calculated in a plate are compared with experimental surface temperature measurements recorded by means of infrared thermography and thermocouples during laser welding. In this model the source energy may be provide all along or only on a part of the plate thickness depending on the depth of the experimental seam.

\section{Model}

The homogeneous slab is supposed infinite in both directions $x$ and $y$, and with thickness $L$ in the $z$ direction (fig. 1).

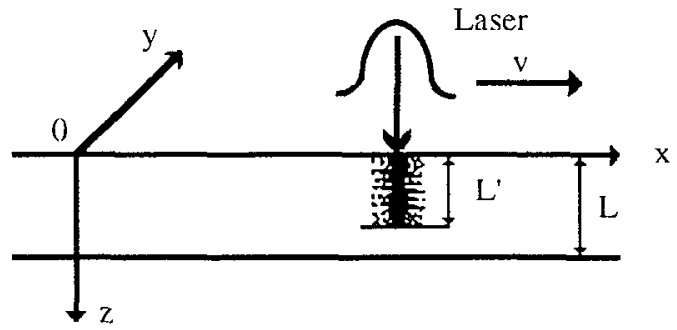

Figure 1 : diagram of the model 
Thermal material properties are assumed to be constant, the power density source is assumed to have a gaussian distribution in the $\mathrm{x}$ and $\mathrm{y}$ directions and is distributed over $\mathrm{L}^{\prime}$ in the $\mathrm{z}$ direction.

The externat exchanges are simulated with a heat transfer coefficient $h$, this assumption has no influences on the result because the main heat transfer is carried out inside the material and the radiative energy lost is included in the absorbed energy.

Given the above assumptions, the temperature field is described by the following set of equations :

- Heat equation: $\frac{\partial^{2} \mathrm{~T}}{\partial \mathrm{x}^{2}}+\frac{\partial^{2} \mathrm{~T}}{\partial \mathrm{y}^{2}}+\frac{\partial^{2} \mathrm{~T}}{\partial \mathrm{z}^{2}}+\frac{1}{\mathrm{k}} \mathrm{g}=\frac{1}{\alpha} \frac{\partial \mathrm{T}}{\partial \mathrm{t}}$

for $-\infty<x<+\infty ;-\infty<y<+\infty ; 0<z<L$

$g=\frac{\Phi}{2 \pi r^{2} L^{\prime}} \exp \left[-\frac{(x-v t)^{2}}{2 r^{2}}-\frac{y^{2}}{2 r^{2}}\right] \quad$ for $0<z<L^{\prime}$ and $t>0$

with $g=0$ for $L^{\prime}<z<L$ and $i>0$

- Boundaries conditions: $\quad-k \frac{\partial T}{\partial z}+h_{1}\left[T-T_{0}\right]=0$ for $z=0$ and $t>0$

$$
k \frac{\partial T}{\partial z}+h_{2}\left[T-T_{0}\right]=0 \text { for } z=L \text { and } t>0
$$

$\mathrm{T}=\mathrm{T}$ () for $\mathrm{x}=+\infty ; \mathrm{x}=-\infty ; \mathrm{y}=+\infty ; \mathrm{y}=-\infty ; 0<\mathrm{z}<\mathrm{L}$ and $\mathrm{t}>0$

- Initial condition : $\mathrm{T}=\mathrm{T}($ ) for $\mathrm{t}=0$ and $-\infty<\mathrm{x}<+\infty ;-\infty<\mathrm{y}<+\infty ; 0<\mathrm{z}<\mathrm{L}$

\section{Solution}

Heat generation $g$ is considered as the sum of heat impulses of po releasing their heat to a point $x^{\prime}, y^{\prime}, z^{\prime}$ all time $1=\tau$, then

$N(x, y, z, t)=T_{0}+\frac{1}{\rho C} \frac{\phi}{\pi L^{\prime}} \sum_{m=1}^{\infty} \frac{1}{N\left(\beta_{m}\right)}\left(\beta_{m} \cos \beta_{m} z+H_{1} \sin \beta_{m} z\right) \ldots$

$\ldots\left(\sin \beta_{m} L^{\prime}-\frac{H_{1}}{\beta_{m}} \cos \beta_{m} L^{\prime}+\frac{H_{1}}{\beta_{m}}\right) \int_{\tau=0}^{l} \frac{1}{2 r^{2}+4 \alpha(t-\tau)} \exp \left\{-\left(\frac{(x-v \tau)^{2}+y^{2}}{2 r^{2}+4 \alpha(t-\tau)}+\alpha \beta_{m}^{2}(t-\tau)\right)\right\} d \tau$

where $H_{1}=\frac{h_{1}}{k}$ and $H_{2}=\frac{h_{2}}{k}$

The eigen values $\beta_{m}$ are the solutions of: $\operatorname{tg} \beta_{m} L=\frac{\beta_{m}\left(\mathrm{H}_{1}+\mathrm{H}_{2}\right)}{\beta_{m}^{2}-\mathrm{H}_{1} \mathrm{H}_{2}}$

and the nom: $N\left(\beta_{m}\right)=\frac{1}{2}\left[\left(\beta_{m^{2}}+H_{1}^{2}\right)\left(L+\frac{\mathrm{H}_{2}}{\beta_{m}^{2}+\mathrm{H}_{2}^{2}}\right)+\mathrm{H}_{1}\right]$

\section{Experiments and results}

The surface temperatures are measured with an infrared camera ATL 100 HGH which scans a line $37 \mathrm{~mm}$ long and has a scanning frequency of $100 \mathrm{~Hz}$.

The thermocouples are located on the back face and used to evaluate the absorbed energy Dconsidered in the model. 
The results are given for the surface temperatures on the welded bead axis, where the oxidation surface state is nearly the same for a given material and a given coating gas. For the mild steel used, the infrared emissivity in the range of $400^{\circ} \mathrm{C}$ to $600^{\circ} \mathrm{C}$ was evaluated at $\varepsilon=0,65$ which is in good agreement with the literature.

The calculated and recorded curves give the temperatures as a function of the distance behind the laser beam. These graphs are only in agreement at a distance of the laser beam corresponding to the solified and oxidized bead surface and this distance depends on the slab thickness and welding parameters. Figure 2 corresponds to optimal welding conditions when the depth of the welded seam is egal to the plate thickness. Figures 3 and 4 correspond to the loss of $20 \%$ in the depth of welded seam resulting from either a decrease in laser power or moving of the beam point focus with regard to the sample surface. Values $\mathrm{P}$ give the incident power of the laser beam and values df give the moving of the focus point from the optimal position, $\mathrm{P}_{\mathrm{a}}$ is the absorbed energy and $v$ the welding speed.

The given temperatures are the mean value of 100 recordings during the sample welding.
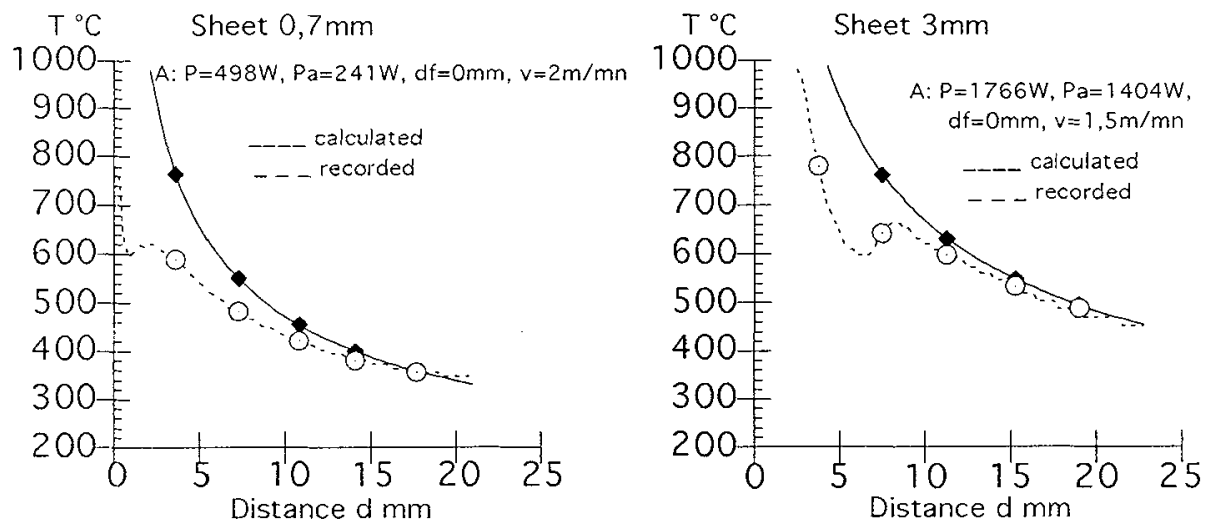

Figure 2: calculated and recorded temperatures in optimal conditions

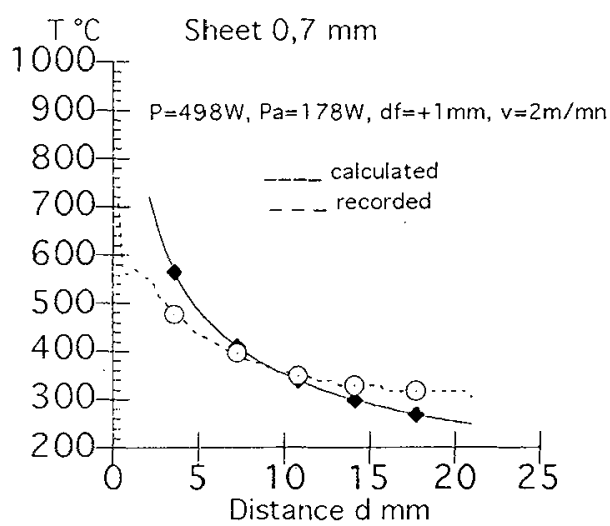

Figure 3 :calculated and recorded temperatures with a laser power decrease.

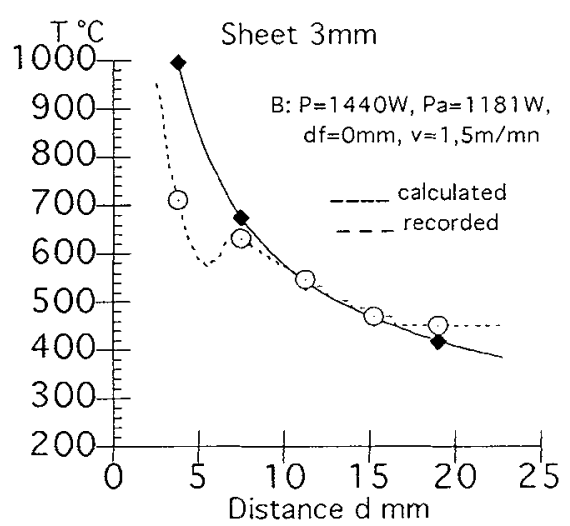

Figure 4 : calculated and recorded temperatures for focus point moving. 
The agreement between calculated and recorded temperatures is fairly good beyond the melted and gas protected area ; for a distance corresponding to $5 \mathrm{~mm}$ for a $0,7 \mathrm{~mm}$ thickness plate and $10 \mathrm{~mm}$ for a $3 \mathrm{~mm}$ one.

The studies on $5 \mathrm{~mm}$ thickness plates would be done beyond a distance of 15 to $20 \mathrm{~mm}$ behind the laser beam.

\section{Conclusion}

The temperatures calculated with the given model are in good agreement with the infrared measured temperatures and the temperatures corresponding to the optimal welding conditions are higher than the temperatures corresponding to a loss in the welded bead penetration.

It seems possible to control the laser welding penetration with superficial temperatures mesurement.

This study has been done in collaboration with the laser service of the Methods Department from the "Régie Nationale des Usines Renault ".

\section{REFERENCES}

11 ROSENTHAL (D.). - Welding Journal suppl. mai 1941 p.220-234

|2| RYKALIN (N.N.). - Soudage et Techniques connexes Vol. 15 nº $^{\circ} 2$ jan. Fev. 1961, p. 5 $-35$

13) CARSLAW (H.S.) et JAEGER (J.C.). - Conduction of heat in solids 1969

14] OZISIK (N.N.). - Heat Conduction 1980 chap.6 p.209

15) SANDERS (O.J.). - Applied Optics Vol $23 \mathrm{n}^{\circ} 1$ jan 1984 p.30

6) MAZUMBER (J.) and STEEN (W.M.). - 1980) J. Applied Phys. 51 p. 941-947

17] ION (J.C), SHERCLIFF (H.R) and ASHBY (M.M). - Diagrams for laser materials processing, Acta Metall. Mater. Vol 40 n 7, 1992, p.1539- 1551

[8] POSTACIOGLUT (N.), KAPADIA (P.), DOWDEN (J.). - A mathematical model of heat conduction in a prolate spheroîdal coordinate system with application to the theory of welding, J. Phys. D : Appl. Phys. 26, 1993, p. $563-573$

19| WEI (P.S.), WU (T.H.), CHOW (Y.T.). - Investigation of high intensite beam caracteristics on welding cavity shape and temperature distribution, J. of Heat Transfer, feb. 1990 vol.112 p.163- 169

[10| CREMERS (D.A.), LEWIS (G.K.) AND KORZEKWA (D.R.). - Measurement of energy deposition during pulsed laser welding, Welding Research supp. july $1991 \mathrm{p} .159 \mathrm{~s}-167 \mathrm{~s}$

111] DARD - THURET (J.), GRABAS (B. ), LAURENT (M.). - Etude du champ de temperature à la suface d'une plaque soumise à l'action d'une source de chaleur mobile, Actes du colloque SFT 1993. 